
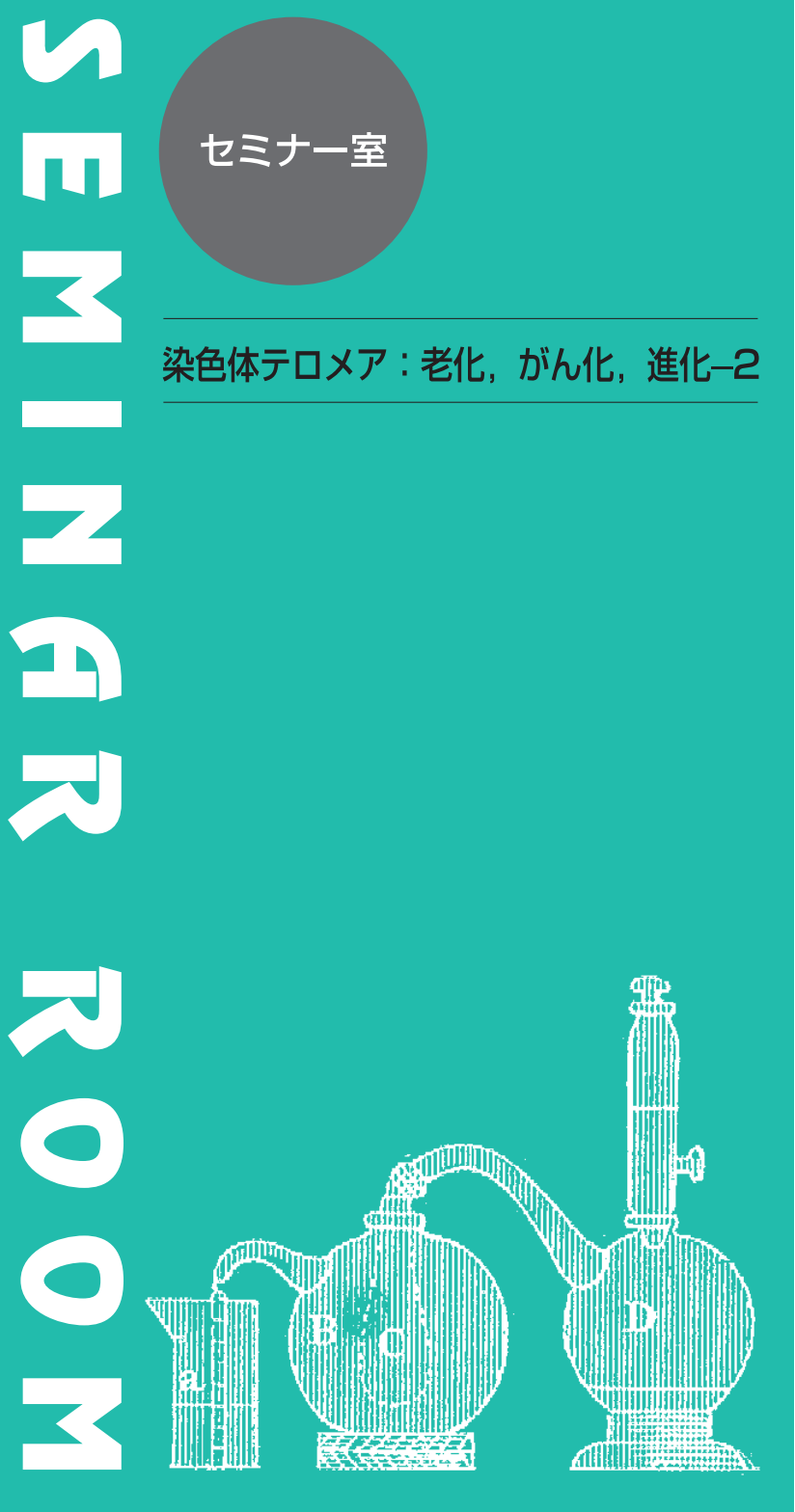

前回は, テロメアの概念が成立した経緯と, テロメア DNA および結合タンパク質がつくるテロメアクロマチ ンの基本構造について概説した。テロメアは, 固有の DNA 配列に特徵的なタンパク質が結合する単なる微視 的な染色体ドメインではない，今回は，テロメアが巨視 的な構造をむつ巨大な機能ドメインであることを概説し たい.

ヘテロクロマチンとは？

核内にある DNA は，M期において凝縮し，顕微鏡に よって個々の染色体を同定できるようになる，染色体 は, その名前のとおり, 塩基性色素によって好染し, そ

\section{ヘテロクロマチンと してのテロXア}

\section{石川冬木}

\author{
京都大学大学院生命科学研究科
}

の構造を詳細に観察することができる。一方, 間期核に おいては, 染色体は脱凝縮しているために, 個々の染色 体を染色だけで区別することはできない，しかし，間期 核においても, 塩基性色素で濃く染まる領域と淡くしか 染まらない領域を区別することができ，それぞれへテロ クロマチンとユークロマチンと呼ぶ. ヘテロクロマチン は，間期にあってもタンパク質と DNA からなるクロマ チンが凝縮して高い密度で存在する領域であり, DNA を染色する色素によっても濃染する. ヘテロクロマチン は, 細胞の種類にかかわらず常に凝縮する領域と, 特定 の細胞種についてのみ凝縮する領域に分けられ，それぞ れ, 構成的へテロクロマチンおよび条件的へテロクロマ チンと呼ぶ. 
構成的へテロクロマチンは，タンデムな繰り返し配列 からなることが特徵的で, DNA を染色する DAPI (4',6diamidino-2-phenylindole) などの蛍光試薬でマウス細 胞の核内にひときわ明るい点状構造物として認識される マウス細胞動原体近傍領域がよく知られている. テロメ アも, テロメア繰り返し配列からなる構成的へテロクロ マチンの一つである. ヘテロクロマチンは, その特徴的 な構造のほかに, ユークロマチンと対比されるいくつか の生物学的特徴を有する. 以下に, テロメアヘテロクロ マチンについて知られていることを述べる.

\section{テロメアヘテロクロマチン}

\section{1. テロメア繰り返し配列}

原核生物は，そのほとんどがゲノム DNAを環状 DNA としてもち，テロメアを有さない，反対に，これま でにゲノム構造が解析されたすべての真核生物は，ゲノ ム DNA を線状 DNA としてもち，テロメアを有する. 真核生物テロメアは，グアニンに富む短いテロメア配列 をタンデムに繰り返すが，その正確な配列とDNA とし ての長さは, 生物種によって少しずつ異なる. 出芽酵母 では， $\left(\mathrm{TG}_{1-3}\right)_{n}$ と記載されるグアニンに富むが配列とし て変化が多いテロメア繰り返し配列が約 100～200 塩基 対存在する. 脊椎動物では, TTAGGG がテロメア繰り 返し配列であり，ヒトでは約 $20 \mathrm{~kb}$ から数 $\mathrm{kb}$ の長さで ある. 実験で汎用される純系マウスでは，50１00 kb の テロメア繰り返し配列をもち, 生物種によってテロメア DNAの長さが異なることがわかる.さらに，ショウ ジョウバエなどの昆虫の一部では, グアニンに富む短い 配列の繰り返しではなく, レトロトランスポゾンがテロ メアに位置する.

\section{2. 遺伝子サイレンシング}

遺伝子の転写レベルは，遺伝子の DNA 配列ととも に，遺伝子がゲノム中のどこに存在するかによって影響 される. 古く, ショウジョウバエにおいて, 通常の位置 では活発に転写している遺伝子を人為的に動原体近傍に 移動させると, その発現が著しく低下することが知られ ていた.この現象は, 同じ遺伝子配列をもつ遺伝子が, その位置によって発現に影響を受けることから，位置効 果 (position effect) として知られており, 今日, エピ ジェネティックスによって制御される遺伝子機能の一つ として考えられている. 1990 年, Gottchling らは, 出芽 酵母でマーカー遺伝子をテロメア近傍に移動させると, その発現がテロメアからの距離に応じて低下することを
見いだし，テロメアの位置効果として報告した ${ }^{(1)}$. これ は, 今日, テロメアに打ける遺伝子サイレンシングとし て知られており, ヒト細胞でも確認されている。一般に, テロメア近傍に生理的な意義をもつと思われる遺伝子は ほとんど存在しないので, テロメア位置効果は, 人為的 にレポーター遺伝子をテロメア近傍に挿入したときに観 察される非生理的な現象と考えられている。しかし，栄 養要求性遺伝子などをレポーター遺伝子として用いるこ とにより, 遺伝子サイレンシングは簡便に測定でき, そ の効果はテロメアクロマチンによってもたらされるの で，遺伝子サイレンシングを指標としたテロメアクロマ チンの解析は酵母において特に汎用されている. ヘテロ クロマチンはまた, 遺伝子組換えが起こりにくい領域と しても知られている. 酵母は遺伝子相同組換えを効率よ く起こすが，テロメアやセントロメアなどのへテロクロ マチンを標的に相同組換えを起こすことは実験的に困難 を伴うことが多い。

\section{3. ヘテロクロマチンのタンパク質と DNA の結合様式 の特徵}

構成的ヘテロクロマチン DNA の特徵は, 特定の配列 がタンデムに繰り返されていることである (図 1-A).こ のような繰り返し配列は, テロメア以外にも, セントロ メア，rDNA などに認められ，それぞれ特異的結合夕ン パク質とともにヘテロクロマチンと呼ばれる高次構造体 を形成して, 遺伝子発現の抑制（サイレンシング）や DNA 組換えの抑制などを特徴としている (B).これらの ヘテロクロマチン繰り返し配列特異的な DNA 結合タン パク質の特徵は, タンパク質が二量体を形成して, DNA と 2 個所で結合することである $(\mathrm{C})$. タンパク質の結合 部位はタンデムに繰り返されているので, タンパク質が 二量体をつくる組み合わせが，前後にずれることがあり うる $(\mathrm{D} \sim \mathrm{E})$. このように, 結合タンパク質は繰り返し DNA 上で二量体形成の相手を変えながら，さまざまな 組み合わせで DNA に結合する。一般に, 複合体は, そ の構成要素間の結合の組み合わせの多様性が多ければ多 いほど安定である.したがって, 繰り返し配列に対して 二量体形成可能な DNA 結合タンパク質が結合するへテ ロクロマチンは, きわめて安定な構造体であるといえ る.

\section{4. ヘテロクロマチンのスプレッディング}

ChIP (chromatin immunoprecipitation) 法は, 目的 タンパク質が結合する DNA 領域を同定するために汎用 される実験技術である，Grunstein らは，ChIP 法を用 


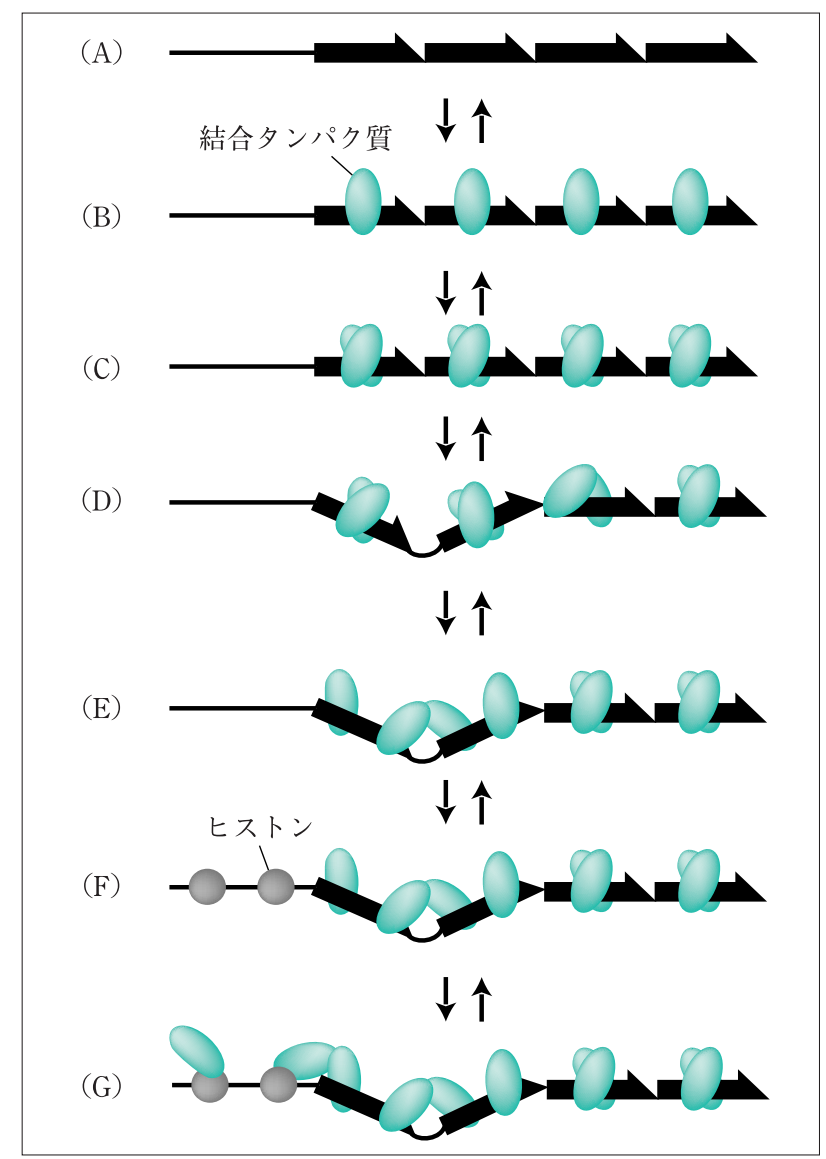

図 1 - 構成的ヘテロクロマチンがとりうる高次構造

(A) テロメアを含めた構成的へテロクロマチンは，タンデムな繰 り返し DNA からなる。(B) 繰り返し配列には，その配列を特異 的に認識して結合するタンパク質がある. (C) 結合タンパク質は 二量体として DNA に結合することが多い. (D, E) 繰り返し配列 間で二量体が形成されることもある。(F) 周囲の DNA には, 七 ストンからなるヌクレオソームが存在する。 $(\mathrm{G})$ 繰り返し配列結 合タンパク質は，自身で二量体をつくるほか，ヒストンと結合 する場合がある.この場合, 繰り返し DNA がない周囲の配列 にもスプレッディングする.

いて, 出芽酵母テロメア結合タンパク質がテロメアに存 在するのみならず，テロメア配列よりも内側のサブテロ メア領域にも結合していること，これらのタンパク質を 過剩発現させると, 結合領域がさらに内側に伸長するこ とを見いだした (2). このように，繰り返し配列はへテロ クロマチン形成の核となるが，ヘテロクロマチンタンパ ク質は, 繰り返し配列と周囲の境界を越えて広がること ができ，これをへテロクロマチンのスプレッディングと いう。

この現象は, テロメア結合タンパク質が, ゲノム全体 に結合するヌクレオソームの構成要素ヒストンと相互作 用をすることによって説明されている. すなわち, テロ メア結合タンパク質の二量体形成の組み合わせがダイナ ミックに変化することで，テロメア DNA と結合しなが
ら，二量体形成をしていない単量体タンパク質が一過的 に現われる（図 1-F)。このような単量体は，テロメアよ りセントロメア側のサブテロメア領域にあるヒストンと 一過的に結合するテロメア結合タンパク質と二量体を形 成することによって安定に，テロメア・サブテロメア境 界領域に結合しうる $(\mathrm{G})$.

\section{5. テロメアヘテロクロマチンのシナプス形成}

前項では，テロメア DNA に沿った一次元方向におい てテロメアクロマチンがダイナミックに結合様式を変化 させ, 安定な複合体を形成することを述べた。この場合, 結合タンパク質は近隣の DNA 結合タンパク質との間で 結合相手を変えるので，いわば DNA 上をシスでクロマ チンの構造変化が起こると考えられる。この考えをさら に発展させると，ある繰り返し配列に結合するタンパク 質が，DNA 上では遠く離れた繰り返し配列に結合する タンパク質と二量体を形成する可能性が考えられる（図 2).このトランスで起こる結合タンパク質の二量体化 は，DNA を折りたたむ結果となり，テロメアは一次元

(A)

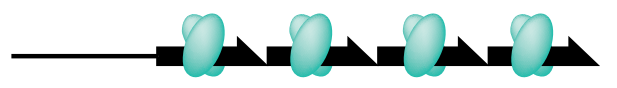

(B)

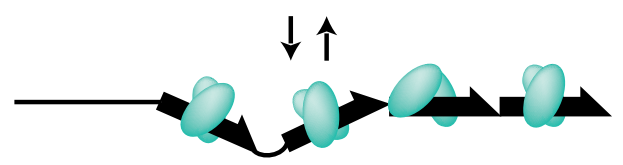

\section{$\downarrow \uparrow$}

(C)

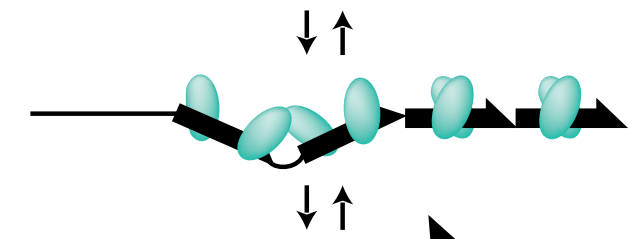

(D)

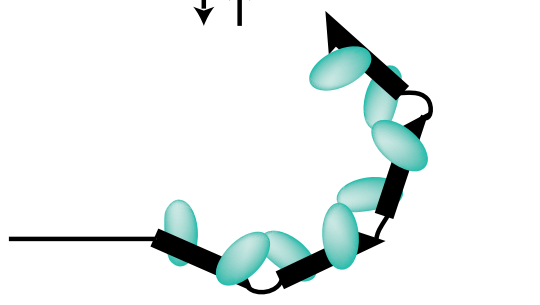

(E)

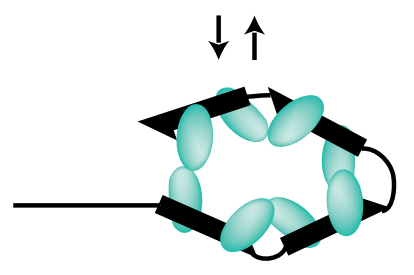

図 2ロヘテロクロマチンのシナプス形成

DNA が折りたたまれることで, DNA 上では離れた位置にある ヘテロクロマチンタンパク質が直接二量体を形成し, ヘテロク ロマチンが空間的な高次構造をとることができる. 
から三次元的な構造体を生むことになる．これをテロメ アのシナプス形成という。 シナプス形成はいくつかの生 物学的意義をもつが, 中でもシナプスという三次元構造 の内部にテロメア DNA の最末端が埋まった状態をつく ることにより, 末端を保護するテロメアの機能を遂行で きるであろう。同じような仮説として，DNA 末端を内 側の DNA とD ループ構造を形成させることでできる 投げ縄構造, t-loop を挙げることができる.

\section{6. ヘテロクロマチンのシナプス形成の意義}

ヘテロクロマチンは, テロメア以外にもセントロメア 近傍, rDNAなどで認められる。これらは, 細胞がゲノ ムを正確に子棌細胞に伝えたり, 細胞の生存に必須の重 要な機能ドメインである. それでは, ヘテロクロマチン に特徵的なシナプス構造はどのような生物学的意義をも つのであろうか?

一般に, ゲノム内の繰り返し配列は, 同じ配列どうし が DNA 相同組換えを起こしやすい. それが異なる染色 体間で起きたときに, 染色体どうしの融合が生じる（図 3-A〜C). また， 1 個所の繰り返し配列を構成する繰り 返しの間で相同組換えが起こると, その間の繰り返し
DNA が失われる $(\mathrm{D} \sim \mathrm{E})$. 実際, DNA 相同組換えの立進 によるテロメアの急速な短小化が酵母やヒト腫瘍細胞で 観察されている.さらに, サブテロメア領域には, レト ロトランスポゾンが多く観察され，その転写を抑制して さらなるレトロトランスポゾンの増殖を防ぐことは, 長 い進化の過程において，ゲノムが安定して存在するため に重要だろう。DNA 相同組換えや遺伝子転写が起こる ためには，それに必要なタンパク質因子が周囲より DNA に作用する必要がある。 ヘテロクロマチンは, シ ナプス形成をすることで, それらのトランス因子が接近 することを防ぎ，ゲノムが不安定化することを防いでい ると考えられる(図 4-A).

テロメアヘテロクロマチンに生理的なトランス因子 が作用する仕組み

前節において, 繰り返し DNA からなる構成的へテロ クロマチンは, DNA 相同組換えやレトロトランスポゾ ンの転写などのゲノムを不安定化する原因を除くため に, シナプスとして立体的な構造障壁をつくり, 組換え 因子や転写因子などのトランス因子が作用できないよう にしていると述べた。この場合, ゲノム不安定性につな
(A)

(B)

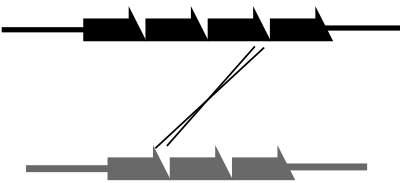

(C)

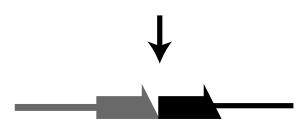

(D)

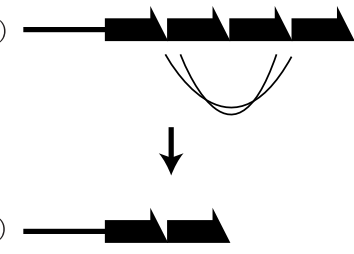

図 3 ・繰り返し配列はゲノムの不安定化を促進する

$(\mathrm{A} \sim \mathrm{C})$ 異なる染色体上の繰り返し配列が DNA 相同組換えを起こすことで，融合異常染色体が形成される，(D〜E) 同じテロメアを構 成する繰り返し配列どうしの組換えにより, ワンステップでテロメア長が急激に減少する.

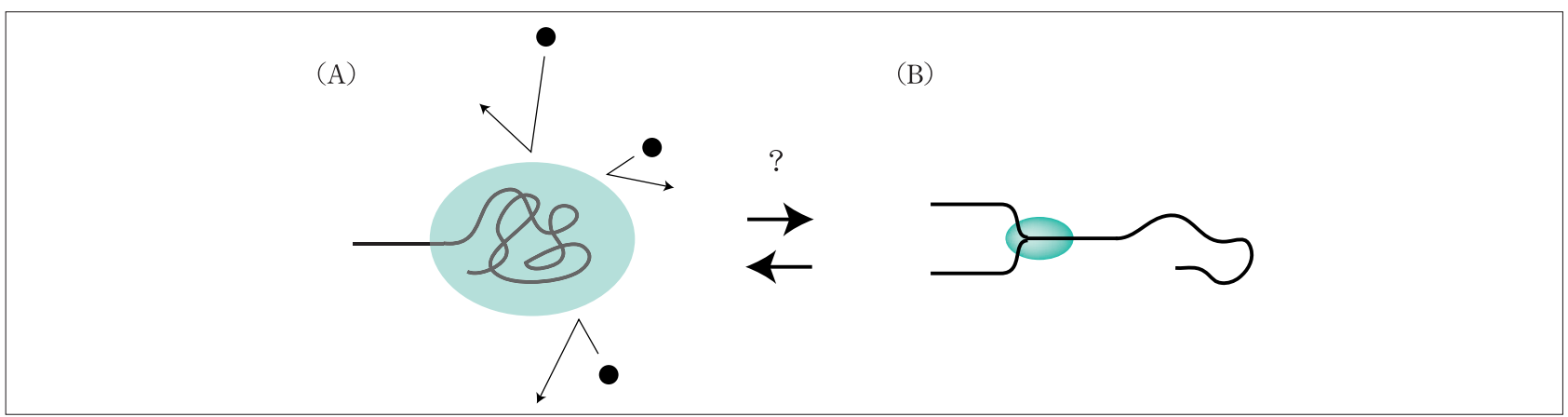

図 4 ロヘテロクロマチンはトランス因子の作用を阻止する

(A) ヘテロクロマチンがつくる高次構造は, 周囲より DNA 組換え因子や転写因子などのゲノムを不安定化するトランス因子が接近し て作用することを防ぐ。(B) DNA 複製装置など, 生理的に必要な DNA 反応を行なうトランス因子が作用するときには, シナプスが より開いた状態となり，反応を容易にするはずである. 
がるトランス因子の排除は合目的的であるが，生理的な トランス因子を排除すると，正常な DNA 代謝が行なわ れず，ゲノムの不安定性を促進してしまうことになる.

特に重要なのは, 複製装置である. 知られているすべ てのテロメア配列は, 内側から複製反応を進める複製装 置がテロメアに向かって進行し，テロメアの複製が完了 する，テロメアシナプス構造がトランス因子の作用を妨 げるとすれば，同様に複製装置の接近も妨げるはずであ り, その場合, テロメア複製が不調に終わる可能性があ る.

$\mathrm{S}$ 期のテロメア複製時に，どのようにして複製装置が テロメアに作用可能となり, 終了後再びシナプス構造を
回復するのかは, 十分に明らかになっていない。最近, de Lange のグループにより, 哺乳類テロメア結合タン パク質である TRF1 が，テロメアの複製を促進すること が報告された ${ }^{(3)}$.これがどのような分子機構でもたらさ れるのかは, 今後, 明らかにすべき重要な課題である.

\section{文献}

1) D. E. Gottschling, O. M. Aparicio, B. L. Billington \& V. A. Zakian : Cell, 63, 751 (1990).

2) A. Hecht, S. Strahl-Bolsinger \& M. Grunstein: Nature, 383, 92 (1996).

3) A. Sfeir, S. T. Kosiyatrakul, D. Hockemeyer, S. L. MacRae, J. Karlseder, C. L. Schildkraut \& T. de Lange : Cell, 138, 90 (2009).

\section{プロフィル}

五味＼cjkstart剣二（Kenji Gomi）＜略歴>1997 年横浜市立大学文理学部理科生物学課程卒 業/1999 年同大学大学院総合理学研究科 博士前期課程修了 / 2002 年愛媛大学大学 院連合農学研究科博士課程修了/同年生物 系特定産業技術研究推進機構派遣研究員 (名古屋大学) $/ 2003$ 年名古屋大学産学官 連携研究員 $/ 2004$ 年(独) 農業生物資源研 究所博士研究員 $/ 2007$ 年京都大学生態学 研究センター非常勤講師 $/ 2008$ 年香川大 学農学部助教, 現在にいたるく研究テーマ 之抱負 $>$ 植物の病害虫抵抗性機構の分子生 物学的解析. 植物が移動せずに様々な環境 ストレスにその場で耐えている仕組みを解 明したいく趣味 >京都旅行

坂村 貞雄 (Sadao Sakamura) <略歴> 1948 年北海道大学農学部農芸化学科卒業 ／同年同大学農学部農芸化学科副手／1949 年同助手 $/ 1960$ 年同助教授 $/ 1968$ 年同教 授 / 1989 年同大学定年退職 / 1990 年帯広 畜産大学学長 $(\sim 1996$ 年 $)<$ 趣味 $>$ 庭先野 菜づくり

里見 正隆 (Masataka Satomi) <略歴> 平成 4 年東京水産大学 (現 東京海洋大学) 水産学部食品生産学科卒業 $/ 9$ 年同大学大 学院水産学研究科博士後期課程修了/同年
水産庁中央水産研究所加工流通部農林水産 技官 $/ 13$ 年(独) 水産総合研究センター(改 組) $/ 16$ 年同研究センター在外研究員 (米 国カリフォルニア工科大学ジェット推進研 究所) $/ 17$ 年同主任研究員, 現在にいたる <研究テーマと抱負 $>$ 水産発酵食品のヒス 夕ミン生成好塩性乳酸菌. 特にヒスタミン 生成能の伝播機構について<趣味 $>$ 水泳, クラシック音楽の鑑賞, 楽器 (ビオラ) 演奏

蓼沼 誠 (Makoto Tadenuma) <略 歴>1960 年東京大学農学部農芸化学科卒 業／同年国税庁醸造試験所／1972 年同所 主任研究員 / 1975 年広島国税局主任鑑定 官 / 1977 年東京国税局主任鑑定官 / 1979 年国税庁鑑定企画官補佐 / 1981 年同庁醸 造試験所第 2 研究室長 $/ 1989$ 年同庁鑑定 企画官 $/ 1991$ 年同庁醸造試験所第 1 研究 室長 / 1993 年同所長 / 1995 年(財) 日本醸 造協会常務理事 / 2000 年同副会長 / 2004 年同会長, 現在にいたるく研究テーマと抱 負＞醇造学を通して日本の釀造物の良さを 消費者に知っていただくく趣味 >海釣り, 各地の珍味を賞味しながらのスクーバダイ ビング

田中 雄二 (Yuji Tanaka) <略歴> 1991 年九州工業大学工学部工業化学科卒
業 / 1993 年同大学大学院工学研究科物質 工学専攻博士前期課程修了 / 1996 年同博 士後期課程修了/同年日本学術振興会特別 研究員 / 1999 年九州大学有機化学基礎研 究センター研究員/同年科学技術振興事業 団研究員 / 2000 年渡辺化学工業(株) / 2005 年九州共立大学工学部生命物質化学 科講師 $/ 2009$ 年同大学工学部生命物質化 学科准教授 / 2010 年同大学共通教育セン 夕ー准教授, 現在にいたるく研究テーマと 抱負>コラーゲンモデルペプチドを用いた 界面活性剂様化合物に関する研究 <趣味 $>$ 鉄道旅行，打城めぐり

千葉 誠哉（Seiya Chiba） Vol. 46, No. 12 , p. 871 参照

橋 本 誠 (Makoto Hashimoto) <略 歴 $>1989$ 年北海道大学薬学部卒業 / 1995 年同大学大学院薬学研究科博士後期課程修 了/同年日本学術振興会特別研究員 (富山 医科薬科大学和漢薬研究所) $/ 1997$ 年帯広 畜産大学畜産学部助手 $/ 2003$ 年同助教授 $/ 2009$ 年北海道大学大学院農学研究院准 教授，現在にいたる。この間，1999 年英国 バース大学博士研究員 ( 2000 年) <研究 テーマと抱負 $>$ 生物有機化学, 化学生物学 $<$ 趣味 $>$ 音楽鑑賞 